\title{
EPIDEMIOLOGY OF HUMAN ROTAVIRUS TYPES 1 AND 2 AS STUDIED BY ENZYME-LINKED IMMUNOSORBENT ASSAY
}

\author{
ROBERT H. YOLKEN, M.D., RICHARD G. WYATT, M.D., GEORGES HISSES, M.D., CARL D. BRANDT, PH.D., \\ WILLIAM J. RODRIGUEZ, M.D., HYUN WHA KIM, M.D., ROBERT H. PARROTT, M.D., JUAN J. URRUTIA, M.D., \\ LEONARDO MATA, D.Sc., HARRY B. GREENBERG, M.D., ALBERT Z. KAPIKIAN, M.D., \\ AND ROBERT M. CHANOCK, M.D.
}

\author{
With the technical assistance of Barbara Barbour and Lula Tatum
}

\begin{abstract}
To determine the relative importance of two known serotypes of human rotavirus, we developed an enzyme-linked immunosorbent assay to differentiate serotype-specific rotavirus antigen and antibody. Using this technic, we studied the epidemiology of the two serotypes in acute gastroenteritis. Seventy-seven per cent of $\mathbf{4 1 4}$ rotavirus isolates were Type 2 , and the remainder were Type 1 . The serotype distribution was similar in specimens from children in Washington D.C., and other parts of the world. Sero-
\end{abstract}

$\mathbf{R}$ OTAVIRUS is an important cause of gastroenteritis of infants and children in many parts of the world." 2 Because the virus does not grow effi-ci,ently in tissue culture, conventional neutralization "methods cannot be used to examine its serotypic variations."' Recently, two human rotavirus serotypes were distinguished by complement fixation,' immune electron microscopy' and immunofluorescence. ${ }^{6}$ The latter two methods are not practical for serotyping of large numbers of rotavirus-positive specimens whereas complement fixation is not sensitive enough for use with low-titered preparations.

We recently described the technic of enzyme-linked immunosorbent assay for the detection of rotavirus antigen and antibody.'"" This assay is similar in design to radioimmunoassay but uses an enzyme instead of a radioactive isotope to quantitate binding of immunoglobulin. We modified the basic assay for detection of rotavirus serotypes and used this new procedure to study the epidemiology of these viruses.

\section{MATERIALS AND METHODS}

\section{Specimens}

'Stool specimens containing rotavirus were collected from 278 in-il. nts and children with gastroenteritis living in the Washington, D.C., area. From January, 1974, to October, 1976, only hospitalized patients were studied, whereas from November, 1976, to May, 1978, specimens from both inpatients and outpatients were available. This population has been described in detail.' In addition, 136 rotaviruscontaining specimens were available from children with and without gastroenteritis from other localities throughout the world. Included were rotavirus-positive stool specimens obtained

From the Laboratory of Infectious Diseases, National Institutes of Health, Bethesda, MD, Department of Microbiology, Free University of Brussels, Belgium, and the Research Foundation of the Children's Hospital National Medical Center and Department of Child Health and Development, George Washington University School of Health Sciences, Washington, DC; Institute of Nutrition of Central America and Panama, Guatemala: University of Costa Rica, San Jose (address reprint requests to Dr. Yolken at the Laboratory of Infectious Diseases, National Institute of Allergy and Infectious Diseases, Bldg. 7, Room 107, National Institutes of Health, Bethesda, MD 20014),

Supported in part by a grant (AI 01528-22) from and contracts ( NO 1 AI 1209 and AI 72535) with the National Institute of Allergy and Infectious Diseases. epidemiologic studies revealed that most children living in the Washington, D.C., area acquired antibody to both types by the age of two years. An analysis of children who were reinfected indicated that sequential infections usually involved different serotypes and that illness caused by one serotype did not provide resistance to illness caused by the other serotype. These results suggest that, to be completely effective, a vaccine must provide resistance to both serotypes. ( N Engi J Med 299:1156-1161, 1978)

from a cohort of 19 children living in a rural village in Guatema-la who were sampled at regular intervals and during episodes of gastroenteritis. This population has also been described in detail." The specimens were tested as filtrates or suspensions at a concentration ranging from 2 to 10 per cent. Suspensions containing visible solid material were clarified by centrifugation at $2000 \mathrm{rpm}$ for 20 minutes before testing. The specimens were stored at $-70^{\circ} \mathrm{C}$ until tested. For the purposes of statistical analysis a season was defined as the period between October 1 of one year through September 30 of the next year.

Acute-phase and convalescent-phase serum specimens were available from 18 children with gastroenteritis living in the United States. In addition, we examined paired serum samples from 14 adult contacts of children with gastroenteritis and From 10 adult volunteers experimentally infected with Type 2 rotavirus. Also, serum and stool specimens were examined from three separate outbreaks: (A) occurred in a play group in which infection spread to adult contacts; (B) occurred in a family that included an infant index case and her parents; and (C) occurred among sailors aboard a naval vessel. To determine the prevalence of antibody we examined a panel of 422 serum specimens. This panel consisted of acute-phase serum from children admitted to the hospital with predominantly respiratory illness, acute-phase serum from college students with predominantly respiratory illnesses and serum from normal adults, as previously described."

Colostrum was obtained from 43 women, 10 from Fairfax, Virginia, 21 from Costa Rica and 12 from a rural area in Guatemala. In addition, milk samples were obtained from 25 mothers from rural Guatemala and 39 mothers from rural Bangladesh. The specimens of human milk were collected from two to 82 weeks post partum.

\section{Assay}

The systems For enzyme-linked immunosorbent assay were modifications of those used for the detection of antigen and antibody previously described.'-- The antigen assay is outlined as indicated below. First of all, goat anti-rotavirus antibody' is adhered to the well of a microtiter plate. This plate is stored at $4^{\circ} \mathrm{C}$ until use. Secondly, after washing, the test material is added. If rotavirus antigen is present it will adhere to the goat antiserum. Thirdly, after incubation for one hour at $37^{\circ} \mathrm{C}$ or overnight at $4^{\circ} \mathrm{C}$, and washing, serotype-specific guinea-pig anti-rotavirus serum is added. The guinea-pig serum used was prepared by inoculation of complete rotavirus particles purified from human stool by sucrose sedimentation, as previously described.' We also found that guinea-pig serum raised against complete and incomplete particles of a serotype could be made serotype specific for antigen detection by absorption with preparations of tissueculture-grown calf rotavirus. Fourthly, after one hour's incubation at $37^{\circ} \mathrm{C}$ and washing, alkaline-phosphatase-labeled anti-guinea-pig immunoglobulin is added. This mixture 
will react with any guinea-pig serum bound in the previous step. Fifthly, after a final wash to remove unbound enzyme, a substrate solution is added. Enzyme bound in the above step will react with the substrate to produce a visible color, which is measured in a spectrophotometer capable of determining optical density at a specific wavelength through the bottom of a microtiter plate." The entire test is read when a weakly positive control specimen has reached a specified optical-density value. Determinations were expressed in terms of a positive over negative ratio,with the negative being the mean value of four human stools not containing rotavirus.

Initially, the type-specific human rotavirus guinea-pig antiserums were titered against bovine rotavirus (NCDV) by enzyme-linked immunosorbent assay. In subsequent experiments 8 antibody units as measured against NCDV were used to standardize rotavirus group reactivity. To establish variability of the type-specifc assay, three reference strains of human rotavirus Type 1 and three of Type 2 were tested in quadruplicate with their homologous guinea-pig antiserum on five successive days. These experiments revealed a test-to-test standard deviation of the positive/negative values of approximately 8 per cent. Thus, in the serotyping procedure that used the Type 1 and Type 2 antiserums, a posi-tive/negative value that was 3 standard deviations or 24 per cent greater with one of the serum specimens than the other was considered to be indicative of that serotype. Most of the differences observed in positive/negative values between the type-specific serums were considerably greater than 24 per cent.

The enzyme-linked immunosorbent assay for measurement of serotype-specific antibody is outlined as follows: type-specific guinea-pig anti-human rotavirus serum, prepared as described above, is adhered to the well of a microtiter plate; after washing, homotypic rotavirus antigen - in the form of a stool suspension from a germ-free calf infected with human rotavirus, as previously described' - is added, and in addition, a stool suspension from a germ-free calf not infected with rotavirus is added to other wells as a control; after washing, the cross-reacting common rotaviral determinants' $1^{0}$ are blocked by the addition of a calf serum that contains antibody to bovine rotavirus (this serum was obtained from a germfree calf after infection with NCDV), and the plates are stored in this way at $4^{\circ} \mathrm{C}$ until use; and, after another washing, dilutions of the serum or milk are added to wells containing Type 1, Type 2 and control antigen. The plates are then processed for anti-rotaviral IgG or IgA as previously described, with use of specific enzyme-labeled anti-human IgG and anti-human IgA.' The preparation and properties of the anti-human IgG conjugate have previously been described.' The anti-human IgA conjugate was prepared in a similar way from goat antiserum to human IgA. This antiserum was made alpha-chain specific by affinity chromatography isolation of the antibody. (This serum was obtained from Antibodies, Incorporated, Davis, California.)

A panel of 10 serum specimens was tested for type-specific rota-viral antibody of the $\mathrm{IgG}$ class, and 10 colostrums were tested for antibody of the IgA subclass. On five successive days, the mean of the standard deviations of the optical-density readings was 0.06 for the serums and 0.08 for the colostrums. Assay of antibody and measurement of serologic response were performed by the end-point titration method Each specimen was tested with three stool filtrates: one was a control filtrate derived from a gnotobiotic calf inoculated with the Norwalk virus, and the other two were derived from calves experimentally infected with Type 1 or Type 2 human rotavirus. A dilution of serum, milk or colostrum was considered to be positive if it yielded an optical-density value with Type 1 or Type 2 antigen that was 3 standard deviations above that observed in the well containing the control stool filtrate. Specimens tested for antibody activity were diluted in twofold steps starting at 1:10 (human milk or colostrum) or 1:50 (human serum)

For the antibody prevalence survey serums were tested at a single dilution of 1:100 against both test and control antigens as above. As previously described, a positive/negative value of greater than 2.0 at this dilution was considered indicative of the presence of rotavirus antibody to the type tested; the mean absorbance of five rotavirus antibody-negative serum specimens was used for the $N$ value.' Statistical analyses were performed by the chi-square, Fisher's exact test or Student's two-tailed t-test where appropriate.

\section{RESULTS}

Initially a set of reference viruses (previously serotyped with guinea-pig antiserums by complement fixation and immune electron microscopy) were assayed for type-specific antigen by the enzyme-linked immunosorbent assay.' The three Type 1 strains had a mean positive/negative value of 5.6 when tested with guinea-pig anti-rotavirus Type 1 serum and a value of 2.2 when tested with guinea-pig anti-rotavirus Type 2 serum $(\mathrm{P}<0.01)$. Similarly, three Type 2 strains had a positive/negative value of 6.6 when tested with guinea-pig anti-rotavirus Type 2 serum and a value of 2.4 when tested with the Type 1 serum $(\mathrm{P}<0.01)$. Thus, these serotypes were easily differentiated by this method. Rotavirus derived from animal species gave an equal reaction with Type 1 and Type 2 antiserums and thus could be distinguished from the human serotypes.

\section{Distribution of Serotypes}

A total of 278 rotaviruses obtained over a five-year period from pediatric patients with gastroenteritis living in the Washington, D.C., area was serotyped by enzyme-linked immunosorbent assay (Table 1). Overall, 25 per cent of the patients shed rotavirus Type 1 , and 75 per cent Type 2. Nontypable rotavi-ruses were not encountered. There was a marked fluctuation in the temporal distribution of rotaviral sero-types. Thus, whereas Type I strains accounted for 14 per cent of the total from October, 1974, to September, 1976, this serotype made up 30 per cent of the total in the 1976-1977 season, and 43 per cent in the 1977-78 season. In addition, an examination of shorter periods within some of these seasons revealed clustering of cases of one serotype or the other. For ex-

Table f. Distribution of Human Rotavirus Serotypes.

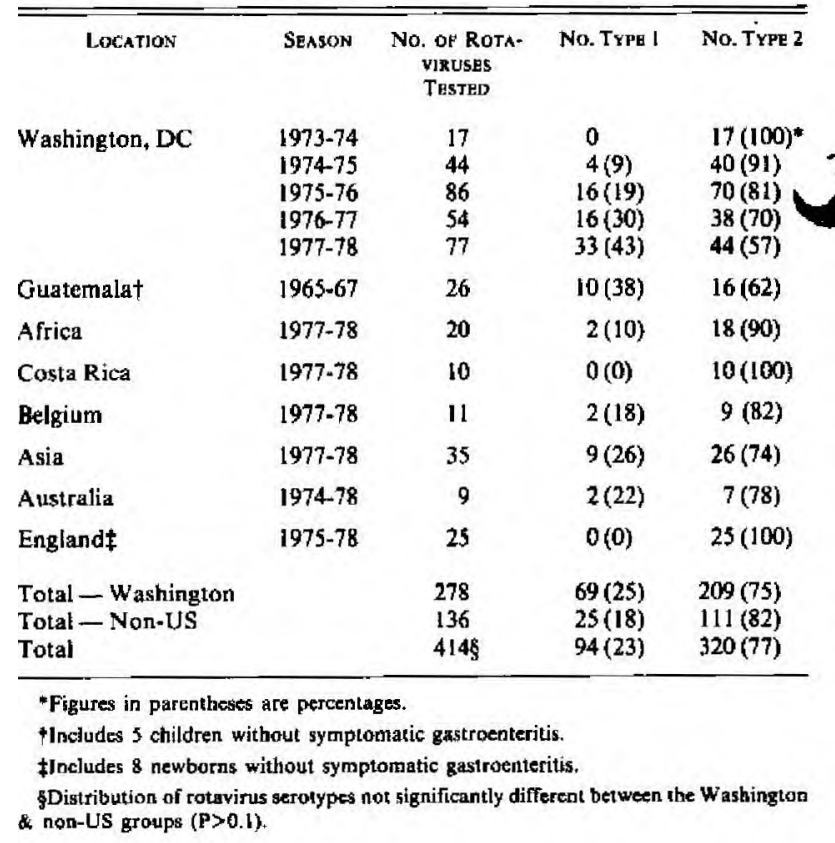


Table 2. Clinical Response to Intection with Rotavirus Type 1 and Type 2 in a Cohort of 19 Children Studied during the First Three Years of Life.

\begin{tabular}{|c|c|c|c|c|c|}
\hline \multirow[t]{2}{*}{ Sterotype } & \multirow[t]{2}{*}{ No. INFECTED } & \multicolumn{4}{|c|}{ NO. WITH INDICATED RESPONSE } \\
\hline & & DIARRHEA & vomiting & DEHYDKATION & NOSYMPTOMS \\
\hline Type I & 11 & 63 & 3 & 0 & $5\} *$ \\
\hline Type 2 & 16 & $16\}$ & 9 & 5 & of \\
\hline
\end{tabular}

ample, there were 20 illnesses associated with rotavirus infection during February, 1978, 10 of which occurred during the first half of the month, and all were identified as Type 2 virus. On the other hand, of the 10 rotavirus illnesses sampled during the second half of the month, seven were Type 1 . The proportion of Type 1 and Type 2 infections among outpatients and inpatients with gastroenteritis was similar. There was no difference in the mean age of patients infected with the two serotypes.

An examination of specimens obtained from other areas of the world also indicated a variability in the

predominance of serotypes (Table 1). However, the overall frequency of Type 1 and Type 2 (18 per cent and 82 per cent respectively) did not differ from that observed in the Washington, D.C., study $(\mathrm{P}>0.1)$.

\section{$\begin{array}{lllllllll}\mathbf{V} & \mathrm{i} & \mathbf{r} & \mathrm{u} & \mathrm{I} & \mathrm{e} & \mathrm{n} & \mathrm{c} & \mathrm{e}\end{array}$}

The relative virulence of the two serotypes could not be determined from the Washington, D.C., study because of its cross-sectional nature. However, in the Guatemalan-cohort study, routine specimens were obtained on a biweekly basis as well as during episodes of gastroenteritis. An analysis of these samples revealed that all 16 Type 2 strains were associated with diarrhea, whereas only six of the 11 Type 1 strains were shed at the time of acute gastroenteritis ( $\mathrm{P}<0.05$ ) (Table 2). Five of the Type 2 infections led to clinically detectable dehydration, whereas this condition was not observed during Type 1 virus infection. This difference approached but did not achieve statistical significance. We also had the opportunity to determine the serotype of rotaviruses detected in stools from eight asymptomatically infected newborns. These infants were in the nursery at a time when pediatric patients were hospitalized with rotaviral gastroenteritis in a nearby ward." Each of the eight rotaviruses from the nursery group and each rotavirus from the patients with gastroenteritis was Type 2 . Thus, Type 2 was capable of causing asymptomatic infection in the normal newborn.

\section{Sequential Infections}

Sequential infections with human rotavirus were documented in nine infants and children - two from the United States and seven from the Guatemalancohort study (Table 3). Eight of the nine children shed a different rotavirus serotype during each of their sequential infections. Type 1 virus caused the first infection in eight of the nine sequential episodes. One child had two sequential Type 1 infections within a 15-month interval, and both were asymptomatic. Another had three separate rotavirus infections; the first two, which were symptomatic, were caused by Type 1 and Type 2 respectively, whereas the third, which was caused by Type 1, was not associated with symptoms.

\section{Specificity of Serotype Immune Response}

Paired serum specimens from the following groups were examined for type-specific human rotaviral antibody: six children with Type 1 infection, 12 children with Type 2 infection, six adult contacts of children with Type 1 infection, eight adult contacts of children with Type 2 infection and 10 adult volunteers experimentally infected with Type 2 human rotavirus.

Table 3. Clinical Manifestations Observed in Infants and Children with Sequential Rotavirus Infections.

\begin{tabular}{|c|c|c|c|c|c|c|c|c|c|c|c|c|c|}
\hline \multirow{3}{*}{$\begin{array}{l}\text { CASE } \\
\text { No." }\end{array}$} & \multirow[t]{3}{*}{ LOCALE } & \multicolumn{6}{|c|}{ First Infection } & \multicolumn{6}{|c|}{ SeCOND Infection } \\
\hline & & \multirow{2}{*}{$\begin{array}{l}\text { AGE } \\
\text { (MO) }\end{array}$} & \multirow[t]{2}{*}{ SEASON } & \multirow[t]{2}{*}{ TYPE: } & \multicolumn{3}{|c|}{ CLINICAL MANIFESTATION } & \multirow{2}{*}{$\begin{array}{l}\text { AOE } \\
\text { (MO) }\end{array}$} & \multirow[t]{2}{*}{ SEASON } & \multirow[t]{2}{*}{ TYPE } & \multicolumn{3}{|c|}{ CLINICAL MANIFESTATION } \\
\hline & & & & & diarrher & vomiting & $\begin{array}{l}\text { dehydra- } \\
\text { nion }\end{array}$ & & & & diarthea & vomiting & $\begin{array}{c}\text { dehydra. } \\
\text { tion }\end{array}$ \\
\hline $1 \dagger$ & US & 3 & $75-76$ & 1 & + & + & + & 14 & $76-77$ & 2 & + & 0 & 0 \\
\hline 2 & us & 2 & $76-77$ & 1 & + & + & 0 & 19 & $77-78$ & 2 & + & 0 & 0 \\
\hline 3 & Guatemala & 3 & $63-64$ & 1 & 0 & 0 & 0 & 7 & $64-65$ & 2 & + & + & 0 \\
\hline 4 & Guatemala & 7 & $64-65$ & 2 & + & 0 & 0 & 23 & $65-66$ & 1 & 0 & 0 & 0 \\
\hline 5 & Guatemula & 11 & $65-66$ & 1 & + & + & 0 & 16 & $65-66$ & 2 & + & + & + \\
\hline $6 \div$ & Guatemala & 3 & $64-65$ & $\mathbf{I}$ & + & 0 & 0 & 6 & $64-65$ & 2 & + & + & 0 \\
\hline 7 & Guatemala & 11 & $64-65$ & 1 & 0 & 0 & 0 & 24 & $65-66$ & 1 & 0 & 0 & 0 \\
\hline 8 & Guatemaja & 13 & $65-66$ & 1 & + & 0 & 0 & 24 & $66-67$ & 2 & + & + & 0 \\
\hline 9 & Guatemala & 13 & $65-66$ & 1 & + & + & 0 & 18 & $65-66$ & 2 & + & + & 0 \\
\hline
\end{tabular}

"Cases 3-9 participated in a prospective study in which stools were collected at regular intervals during periods of health as well as disease." tClinical Course of Case 1 previously deseribed. ${ }^{22}$ 
Table 4. Type 1 and Type 2 Human Rotavirus Outbreaks.

\begin{tabular}{|c|c|c|c|c|c|c|c|}
\hline \multirow[t]{3}{*}{ OUtBReak } & \multirow[t]{3}{*}{ TYPE } & \multicolumn{3}{|c|}{ TEST FOR VIRUS IN FECES } & \multicolumn{3}{|c|}{ SERORESPONSES* } \\
\hline & & \multirow{2}{*}{$\begin{array}{l}\text { NO. OF } \\
\text { PERSONS } \\
\text { TESTED }\end{array}$} & \multicolumn{2}{|c|}{ No. POSITLYE } & \multirow{2}{*}{$\begin{array}{l}\text { NO. OF } \\
\text { PERSONS } \\
\text { TESTED }\end{array}$} & \multicolumn{2}{|c|}{ NO. POSITVE } \\
\hline & & & Type I & Type 2 & & Type I & Type 2 \\
\hline $\begin{array}{l}\text { Playgroup } \\
\text { children \& } \\
\text { their family } \\
\text { contacts }\end{array}$ & 2 & $11+$ & 0 & 6 & 7 & 0 & 7 \\
\hline Family & $\mathbf{I}$ & 2 & 2 & 0 & 3 & 3 & 0 \\
\hline Shipboard & I & 0 & - & - & 3 & 3 & 0 \\
\hline
\end{tabular}

*4-fold or greater rise in antibody (as measured by enzyme-linked immunosorbent assay) during convalescence. tA total of 10 of the 11 in this outbreak had evidence of Type 2 rotavirus infection by
detection of virus in stool or by a seroresponse (or by both).

Although there was some cross-reactivity, the rise in homotypic antibody was greater than the heterotypic response, and most subjects had a fourfold increase in titer only to the infecting serotype.

Specificity of immune response was also examined by study of three discrete outbreaks of rotaviral gastroenteritis by type-specific enzyme-linked immunosorbent assay (Table 4). Outbreak (A) consisted of nine children and 12 adult contacts ill with gastroenteritis. Eight stool specimens and four paired serum specimens were available from the children, and three stools and three paired serum specimens, from the adult contacts. A total of 10 of the 11 patients from whom specimens were available shed Type 2 virus or showed a Type 2 seroresponse whereas none of these patients had evidence of Type 1 infection. In outbreak (B), which involved an infant and both parents, each patient had symptoms of gastroenteritis, and a sero-response to Type $\mathbf{1}$ rotavirus developed. Diarrheal stool samples were available from the mother and the infant, both of whom were found to shed Type 1 rotavirus. Similarly, in outbreak (C), which occurred on a naval vessel, only serologic evidence of Type 1 infection was observed in the three affected persons tested. Unfortunately, stool specimens were not available in this outbreak.

\section{Acquisition of Antibody}

Analysis of the prevalence of antibody to human rotavirus Types 1 and 2 in 422 subjects six months to 60 years of age indicated that infection with both Type 1 and Type 2 viruses occurred at an early age; thus by 18 months of age 85 per cent had antibody to each serotype (Fig_ 1). A difference in prevalence of antibody to Type 1 and Type 2 was not statistically significant for any age group. In addition, there was no year-to-year variation in prevalence of antibody to either serotype among children six months to three years of age tested over the period 1974 through 1977.

\section{Colostral and Milk Antibody}

IgA antibody to the Type 1 and Type 2 rotaviruses was examined in 43 colostral and 64 milk specimens from xromen livina in Ranoladech Fuatamala Cocta
Rica and Washington, D.C. (Table 5). Eighty-eight per cent of the colostral specimens had IgA antibody to Type I rotavirus, and 91 per cent to Type 2 . Although the geometric mean titer to each serotype was lower in milk than in colostrum $(\mathrm{P}<0.05), 88$ per cent of the milks had antibody to Type I, and 88 per cent to Type 2. Only two specimens (both milk) lacked detectable antibody to both serotypes. The difference in geometric mean antibody titer to Type 1 and Type 2 was not statistically significant for colostrum or milk.

The ability of a nursing mother to respond to infection with an antibody rise to a specific rotaviral type was documented in the case of a mother and child who were infected with rotavirus at about the same time. The rotavirus in the child's stool was identified as Type 1. The mother's stool, which was positive for rotavirus by electron microscopy, was not available for serotyping. The mother had no detectable milk IgA antibody to Type 1 before infection but had a titer of 1 : 32037 days after infection. Her preinfection milk IgA antibody titer to rotavirus Type 2 was 1:80, and this titer did not change after infection.

\section{DIscussion}

The enzyme-linked immunosorbent assay was able to identify the serotype of rotaviruses derived from children living in a variety of locales. These findings confirm those of Zissis and Lambert, who described two rotaviral serotypes with the technics of complement fixation and immune electron microscopy.' The distinctness of these serotypes is clear from the temporal variation in pattern of serotypes, the serotypespecific immune response to infection and the homogeneity of the three outbreaks studied. Additional

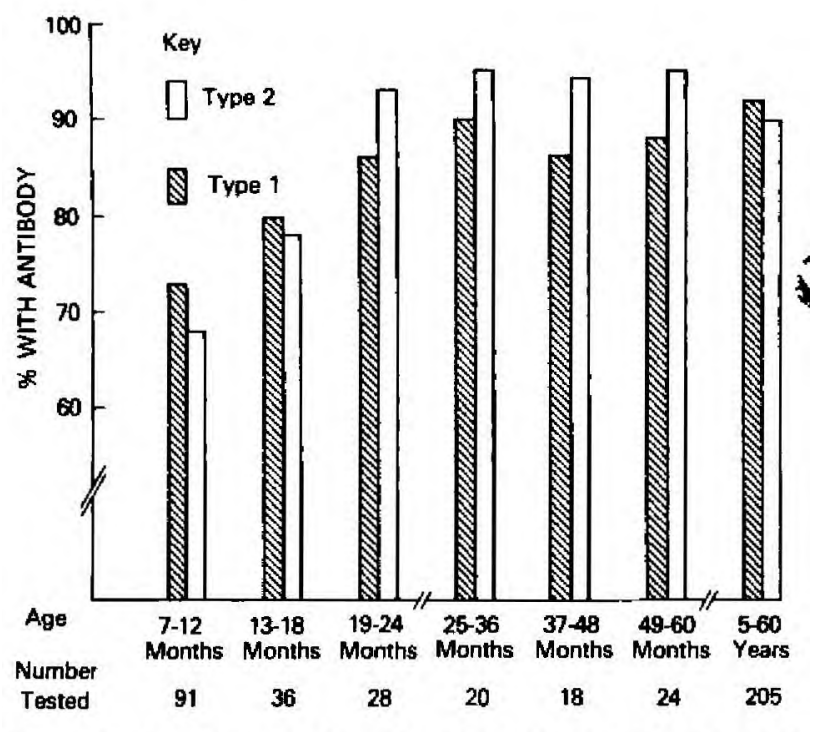

Figure 1. Acquisition of Antibody to Rotavirus Type 1 and Type 2 According to Age.

The serum specimens were obtained from persons six months to 60 years of age living in the Washington, D.C., area. 
Table 5. Type-Specific Rotavirus IgA Antibody in Colostrum and Milk.

\begin{tabular}{|c|c|c|c|c|c|c|}
\hline \multirow{2}{*}{$\begin{array}{c}\text { MateRIAL } \\
\text { TESTEP }\end{array}$} & \multirow[t]{2}{*}{ LOCATION } & \multirow{2}{*}{$\begin{array}{l}\text { No. of } \\
\text { SUBJECTS } \\
\text { TESTED }\end{array}$} & \multicolumn{2}{|r|}{ TYPE I } & \multicolumn{2}{|r|}{ TYPE 2} \\
\hline & & & GMT* & $\begin{array}{l}\text { NO. WITH } \\
\text { DETECTABI.E } \\
\text { ANTIBODY }\end{array}$ & GMT & $\begin{array}{l}\text { NO. WITH } \\
\text { DETRCTABLE } \\
\text { ANTIBODY }\end{array}$ \\
\hline Colostrum & $\begin{array}{l}\text { Guatemala } \\
\text { Costa Rica } \\
\text { US }\end{array}$ & $\begin{array}{l}10 \\
21 \\
12\end{array}$ & $\begin{array}{l}204 \\
165 \\
226\end{array}$ & $\begin{array}{l}9(90) \dagger \\
18(86) \\
11(92)\end{array}$ & $\begin{array}{l}186 \\
237 \\
259\end{array}$ & $\begin{array}{r}9(90) \\
19(90) \\
11(92)\end{array}$ \\
\hline Milkł & $\begin{array}{l}\text { Guatemala } \\
\text { Bangladesh }\end{array}$ & $\begin{array}{l}25 \S \\
39 \S\end{array}$ & $\begin{array}{l}50 \\
70\end{array}$ & $\begin{array}{l}21(84) \\
35(90)\end{array}$ & $\begin{array}{l}70 \\
58\end{array}$ & $\begin{array}{l}22(88) \\
34(87)\end{array}$ \\
\hline
\end{tabular}

*Geonetric mean titer (reciprocal) - includes all specimens tested.

+Figures in parentheses are percentages. $\$ 2-82$ wk post partum.

IIncludes $\mathrm{I}$ specimen in each group with oo detectable antibody to either serotype; otherwise all specimens tested had antibody to at least I serolype.

convincing evidence for immunologic distinctness of the rotaviral serotypes emerged from the study of sequential illnesses caused by rotavirus. In each case the first illness was associated with Type 1, and the second illness with Type 2. This observation suggests that infection with Type 1 does not induce noteworthy resistance to Type 2 . In the two cases in which a patient was reinfected with the same serotype the second infection was asymptomatic. Our observations confirm those of Fonteyne et al., who also found that sequential infections were caused by different serotypes.16,22

With the enzyme-linked immunosorbent assay, each of the 414 rotavirus strains tested could be classified as Type 1 or Type 2. Since the identification of serotype was defined as a greater reactivity with one reference serum than with the other, it is possible that minor serotypic variations exist that were not detected by this system. Similarly, additional serotypes, as have been reported, 6 might not be detected by our technic if they were more closely related to one established serotype than to the other. Further studies on sequential infections will be necessary to determine the number of serotypes that are important in human infection.

Although only 25 per cent of the isolates from symptomatic children from the Washington area over a five-year period were Type 1, seroepidemiologic analysis revealed that 85 per cent of children had detectable antibody to both serotypes early in life, suggesting that the clinical expression of Type 2 virus infection is more pronounced than that of Type 1 virus. Observations made during the cohort study of Guatemalan children support this suggestion. Infection with Type 1 was asymptomatic in 45 per cent of cases, whereas every Type 2 infection was associated with gastroenteritis. This postulated greater virulence of type of human rotavirus is similar to that previously observed for Type 1 poliovirus, which exceeds the Type 2 and Type 3 polioviruses in neuropathogenicity ${ }^{7}$

One of the fascinating and currently unexplained aspects of rotavirus epidemiology is the frequent occurrence of asymptomatic infection during the new-
Drborn period." ,19 Our analysis of eight such strains frfrom England indicates that each was Type 2 - the sasame type that was associated with gastroenteritis ththat led to admission of older children to the same hrbospital. It is unclear why this serotype failed to indice illness in the newborn whereas it exhibited virulence for older infants.

It has been noted in several studies that breast feeding decreases the incidence of gastroenteritis in

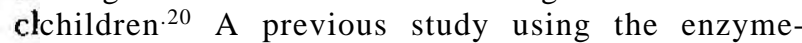
inlinked immunosorbent assay demonstrated presence viof rota-ral antibodies in human colostrum and milk. se15 Ob-rvations made during the present study thindicate at many samples of milk and colostrum atcontain Stibody directed against both serotypes. In tiraddi-tion, the study of sequential milk specimens mother infected with Type 1 rotavirus revealed that she acquired a type-specific IgA antibody response. It is of interest that her child was infected with the rotavirus serotype to which she did not have milk antibody at the time of infection. The role of breast-milk antibody in protection against rotaviral disease and the possibility of augmenting this antibody remain to be determined.

Infantile gastroenteritis is a major cause of morbidity in developed countries and a major cause of mortality in many developing countries of the world. Furthermore, infection with human rotavirus appears to be responsible for a substantial portion of gastroenteritis occurring in children six months to two years of age. ${ }^{4}$ One approach to prevention of this disease in piglets involves the use of a vaccine during infancy to induce active immunity and possibly also during late pregnancy to boost colostral and milk antibodies and thus to provide passive immunity to the nursing infant. ${ }^{21}$ The realization that there are two distinct human rotaviruses that do not appear to provide noteworthy heterotypic immunity suggests that, to be completely effective, a vaccine must induce resistance to both serotypes.

We are indebted to the following investigators for submitting stool, serum, or milk specimens: Dr. Otto Sobeslavaky of World Health Organization, Geneva, Switzerland; Dr. Linda Saif, Ohio Agricultural Research and Development Center, Wooster, Ohio; Drs. Michael Merson and Robert Black, Cholera Research Laboratory, Dacca, Bangladesh; Drs. Ruth Bishop, Don Robertson and Grahm Barnes, Royal Children's Hospital, Melbourne, Australia; Drs. J. Banatavala, Barbara Totterdale and Ian Chrystie, St. Thomas Hospital, London, England; and Dr. Myron Levine, University of Maryland, Baltimore, Maryland.

\section{REFERENCES}

1. Kapikian AZ, Kim HW, Wyatt RG, et al: Human reovirus-like agent as the major pathogen associated with "winter" gastroenteritis in hospitalized infants and young children. N Engl J Med 294:965-972, 1976

2. Middleton Pi, Abbott GD, Szymanski MT, et al: Orbivirus acute gastroenteritis of infancy. Lancet 1:1241-1244, 1974

3. Wyatt RO, Gilt VW, Sereno MM, et al: Probable in-vitro cultivation of human reovirus-like agent of infantile diarrhoea. Lancet 1:98-99, 1976 4. Wyatt RG, Kalica AR, Mebus CA, et al: Reovirus-like agents ( rotaviruses) associated with diarrhea] illness in animals and man. Perspectives in Virology. Vol. 10. Edited by M Pollard. New York, Raven Press, 1978, pp 121-145

S. Zissis G, Lambert JP: Different serotypes of human rotaviruses. Lancet 1:38.39, 1978 
6. Thouless ME, Bryden AS, Flewett TH: Serotypes of human rotavirus. Lancet 1:39, 1978

7. Yolken RH, Kim HW, Clem T, et al: Enzyme-linked immunosorbent assay (ELISA) for detection of human reovirus-like agent of infantile gastroenteritis. Lancet 2:263-266, 1977

8. Yolken RH, Wyatt RG, Kapikian AZ: ELISA for rotavirus. Lancet 2: 819,1977

9. Yolken RH, Wyatt RG, Kim HW, et al: Immunological response to infection with human reovirus-like agent: measurement of antihuman reovirus-like agent immunoglobulin $\mathrm{G}$ and $\mathrm{M}$ levels by the method of enzyme-linked immunosorbent assay. Infect Immun 19: 540-546, 1978

10. Yolken RH, Barbour B, Wyatt RG, et al: Enzyme linked immunosorbent assay for identification of rotaviruses from different animal species. Science 201:259-261, 1978

10a. Wyatt RG, Yolken RH, Urrutia JJ, et al: Diarrhea associated with rotavirus in rural Guatemala: a longitudinal study of 24 infants and young children. Am 1 Trop Med Hyg (in press)

I I. Mata LI, Kronmal RA, Garcia B, et al: Breast-feeding, weaning and the diarrhoea! syndrome in a Guatemalan Indian village. Ciba Found Symp 42: $311.338,1976$

12. Kim HW, Brandt CD, Kapikian AZ, et al: Human reovirus-like agent infection: occurence in adult contacts of pediatric patients with gastroenteritis. JAMA 238i404-407, 1977
13. Kapikian AZ, Greenberg HB, Chne WL, et al: Prevalence of antibody to the Norwalk agent by a newly developed immune adherence hemagglutination assay. J Med Viral (in press)

14. Clem T, Yolken RH: Practical colorimeter for direct measurement of microplates in enzyme immunoassay systems. J Clin Microbial 7:55-58, 1978

15. Yolken RH, Mate L, Urrutia J, et al: Secretary antibody directed against rotavirus in human milk-measurement by means of enzyme-linked immunosorbent assay (ELISA). J Pediatr (in press)

16. Fonteyne .1, Zissis G, Lambert JP: Recurrent rotavirus gastroenteritis. Lancet 1:983, 1978

17. Melnick J: Enteroviruses, Viral Infections of Humans Epidemiology and Control. Edited by AS Evans. New York, Plenum Press. 1976, pp 163-208

18. Totterdell BM, Chrystie IL, Banatvala JE: Rotavirus infections in a maternity unit. Arch Dis Child 51:924-928, 1976

19. Murphy AM, Albrey MB, Crewe EB: Rotavirus infections of neonates. Lancet 2:1149-1I50, 1977

20. Hanson LA. Winberg 3: Breast milk and defense against infection in the newborn. Arch Die Child 47:845-848, 1972

21. Lecce JG, King MW, Mock R: Renvirus-like agent associated with fatal diarrhea in neonatal pigs. Infect Immun 14:816-825, 1976

22. Rodriguez WJ, Kim HW, Brandt CD, et al: Sequential enteric illnesses associated with different rotavirus serotypes. Lancet 2:37, 1978 